\title{
A new Silver Dollar species of Metynnis Cope, 1878 (Characiformes: Serrasalmidae) from Northwestern Brazil and Southern Venezuela
}

\author{
Rafaela Priscila Ota ${ }^{1}$, Lúcia Helena Rapp Py-Daniel ${ }^{2}$ and Michel Jégu ${ }^{3}$
}

\begin{abstract}
A new Metynnis is described from the rio Negro in Brazil and Venezuela, and from black- or clearwater tributaries in Brazil including the rios Parauari, Uatumã, Trombetas, and Sucunduri (the latter belonging to the rio Madeira basin). The new species can be distinguished readily from all congeners by having a high concentration of dark chromatophores on the lateral line scales. It can be further distinguished by the combination of head length 24.3-27.5\% of SL, 13-18 gill-rakers on upper limb and 16-24 gill-rakers on lower limb. The new species is most similar to and likely most closely related to Metynnis hypsauchen. These two species share a similar color pattern, body shape and sexual dimorphism of the anal fin. However, they differ in that $M$. hypsauchen has a lightly pigmented lateral line. The new species is also distinguished from M. hypsauchen by having 56-65 predorsal scales and 90-104 lateral line scales (vs. 36-54, and 65-82, respectively). A detailed osteological description of the new species is provided.

Um novo Metynnis é descrito do rio Negro, no Brasil e Venezuela, e de tributários de água clara ou preta no Brasil, incluindo os rios Parauari, Uatumã, Trombetas e Sucunduri (o último pertencendo à bacia do rio Madeira). A nova espécie pode ser prontamente distinguida de todas as congêneres por possuir escamas da linha lateral com elevada concentração de cromatóforos escuros. Ela pode ser adicionalmente diferenciada por uma combinação de comprimento da cabeça 24,3-27,5\% do CP, 13-18 rastros branquiais no ramo superior e 16-24 rastros branquiais no ramo inferior. A nova espécie é mais similar e provavelmente mais proximamente relacionada à Metynnis hypsauchen. Essas duas espécies compartilham padrão de colorido semelhante, forma do corpo e dimorfismo sexual na nadadeira anal. No entanto, elas diferem na presença de linha lateral com pigmentos mais claros em M. hypsauchen. A nova espécie também pode ser distinguida de M. hypsauchen por apresentar 56-65 escamas pré-dorsais e 90-104 escamas na linha lateral ( $v s .36-54$, e 65-82, respectivamente). Uma descrição osteológica detalhada da nova espécie é fornecida.
\end{abstract}

Keywords: Biogeography, Metynnis hypsauchen, Osteological description, Phylogeny, Taxonomy.

\section{Introduction}

Metynnis Cope, 1878, is one of the most species-rich genera within Serrasalmidae and currently includes 15 valid species. The genus is widely distributed in cis-andean South America, including the Amazon, Orinoco, Paraguay, Paraná and São Francisco river basins, Northeastern Guiana Shield rivers, and coastal rivers from Northeastern Brazil (Zarske \& Géry, 1999, 2008; Jégu, 2003; Pavanelli et al., 2009; Ota, 2015). The taxonomy of the genus is still confused and impeded by high ontogenetic variability and sexual dimorphism that includes the presence versus absence of the anal-fin lobe, the elongation of the first dorsal-fin rays, and variation in body coloration (Zarske \& Géry, 1999; Pavanelli et al., 2009; Ota et al., 2013).
The authors of previous taxonomic reviews involving Metynnis disagree on the number of valid species. Ahl (1923) described nine new species of Metynnis and redescribed others, recognizing a total of 18 species within the genus. Later, Gosline (1951), emphasizing similarities in body shape, counts and measurements among museum specimens, reduced the diversity of Metynnis to only six species. Zarske \& Géry (1999), in the most comprehensive study of this genus, reviewed the type series of all nominal Metynnis taxa and recognized 11 species. Subsequently, Zarske \& Géry (2008) described M. longipinnis Zarske \& Géry, 2008 and M. polystictus Zarske \& Géry, 2008 and confirmed M. goeldii Eigenmann, 1903 as a junior synonym of $M$. lippincottianus (Cope, 1870).

\footnotetext{
'Instituto Nacional de Pesquisas da Amazônia, Programa de Pós-Graduação em Biologia de Água Doce e Pesca Interior, Coleção de Peixes. Avenida André Araújo, 2936, Caixa Postal 2223, 69060-001 Manaus, Amazonas, Brazil. rafaelapota@gmail.com.br (corresponding author) ${ }^{2}$ Instituto Nacional de Pesquisas da Amazônia, Coleção de Peixes, Avenida André Araujo, 2936, Caixa Postal 2223, 69060-001, Manaus, Amazonas, Brazil. lucia.rapp@gmail.com ${ }^{3}$ Laboratoire d'Icthyologie, Muséum National d'Histoire Naturelle, MNHN, Institut de Recherche Pour le Développement, Biologie des Organismes et Ecosystèmes Aquatiques, UMR BOREA, CP26, 43 rue Cuvier, 75231 Paris Cedex 05, France. michel.jegu@gmail.com
} 
In spite of these taxonomic uncertainties, the monophyly of the genus is well accepted and has been corroborated by various authors in both morphological (Machado-Allison, 1982, 1983; Jégu, 2004) and molecular phylogenetic analyses (Ortí et al., 1996, 2008; Calcagnotto et al., 2005; Thompson et al., 2014), with the exception of Cione et al. (2009), which recovered a paraphyletic Metynnis. Species of Metynnis can be easily recognized within Serrasalmidae by having a long adipose-fin base, generally exceeding the distance between the dorsal-fin insertion and adipose-fin origin (Cope, 1878; Eigenmann, 1915; Jégu, 2003). Although representatives of the genus possess two rows of premaxillary teeth, like the herbivorous pacus (Machado-Allison, 1983; Ota et al., 2013), Metynnis has been recovered as being more closely related to piranhas, which are mainly characterized by a single row of premaxillary teeth (Machado-Allison, 1983; Ortí et al., 1996, 2008; Cione et al., 2009).

In the present paper, we describe a new species previously reported as Metynnis hypsauchen (Müller \& Troschel, 1844), due to similarities in color pattern, body shape and sexual dimorphism of the anal fin. The new species is widespread throughout rivers draining the Guiana Shield, including the rio Negro in Brazil and Venezuela, the Uatumã and Trombetas river basins in Brazil. It also occurs inthe northern edge of Brazilian Shield in the Parauari and Sucunduri rivers in Brazil. All of these are black- or clear-water systems.

\section{Material and Methods}

Measurements were taken point-to-point with a caliper to the nearest $0.1 \mathrm{~mm}$, and counts were taken under a stereomicroscope, both on the left side whenever possible. Morphometrics follow Géry (1972), with the following additions: prepectoral distance (from snout to pectoral-fin origin), preanal distance (from snout to anal-fin origin), caudal-peduncle depth (vertical depth taken at the caudal peduncle's center), length of supraoccipital process (from the base to the distal tip of the process), and the distance between base of supraoccipital process and dorsal-fin origin. Body measurements are presented as percentages of standard length (SL), except for subunits of the head, which are expressed as percentages of head length (HL). Meristics follow Zarske \& Géry (1999). Ranges are followed by the values of the holotype in parentheses and indicated with asterisks. Vertebral and supraneural counts were obtained from three skeletonized specimens (INPA 18657 and INPA 52432), designated as "skel." in the species accounts. Vertebral counts include the Weberian apparatus as four elements, and the fused PU1+U1 as a single bone. Osteological terminology follows Eigenmann \& Kennedy (1903), Weitzman (1962), Machado-Allison (1982), and Mattox et al. (2014). Institutional abbreviations are ANSP, Academy of Natural Sciences of Philadelphia, Philadelphia; CAS, California Academy of Sciences, San Francisco; CPUFMT, Coleção de Peixes da Universidade Federal de Mato Grosso, Cuiabá; FMNH, Field Museum of Natural History, Chicago; INPA,
Instituto Nacional de Pesquisas da Amazônia, Manaus; LBP, Laboratório de Biologia e Genética de Peixes do Instituto de Biociência, Botucatu; MBUCV, Museo de Biologia, Universidad Central de Venezuela, Caracas; MCNG, Museo de Ciencias Naturales, Guanare; MCP, Museu de Ciências da PUCRS, Porto Alegre; MHNLS, Museo de Historia Natural La Salle, Caracas; MZUEL, Museu de Zoologia da Universidade Estadual de Londrina, Londrina; MZUSP, Museu de Zoologia da Universidade de São Paulo, São Paulo; NUP, Coleção Ictiológica do Nupélia, Maringá; UFRO-I, Coleção de Peixes da Universidade Federal de Rondônia, Porto Velho; and USNM, National Museum of Natural History, Smithsonian Institution; Washington D.C.

\section{Metynnis melanogrammus, new species}

urn:1sid:zoobank.org:act:9E6F426E-95B9-4938-B8274D222D1BF348

(Figs. 1-8)

Metynnis hypsauchen Zarske \& Géry, 2008: 179 [Guyana: comparison to Metynnis longipinnis: photo].

Metynnis cf. hypsauchen Zeinad \& Prado, 2012: 153 [Brazil, rio Sucunduri, rio Madeira basin: photo].

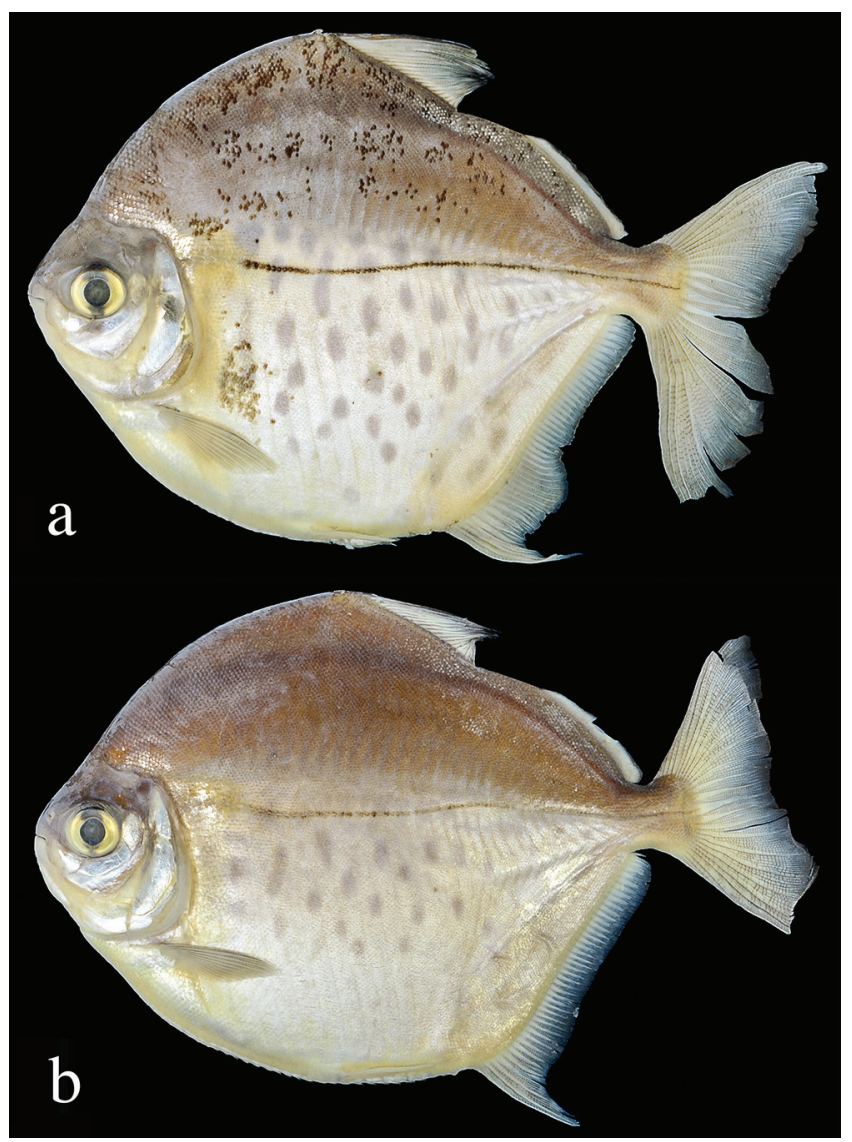

Fig. 1. Metynnis melanogrammus, Brazil, Amazonas, Maués, rio Parauari: a. INPA 52216, male, $141.3 \mathrm{~mm}$ SL, holotype; b. INPA 34811, female, $149.4 \mathrm{~mm}$ SL, paratype. 
Holotype. INPA 52216, male, $141.3 \mathrm{~mm}$ SL, rio Parauari, Monte Sinai community, Maués, Amazonas, Brazil, $4^{\circ} 21^{\prime} 28^{\prime}$ 'S $57^{\circ} 35^{\prime} 54^{\prime \prime} \mathrm{W}, 31$ May 2010, R. R. de Oliveira \& W. Pedroza.

Paratypes. Brazil: Amazonas: ANSP 200146, 2, 142.6$144.3 \mathrm{~mm} \mathrm{SL}$, rio Cucuí, tributary of rio Negro, São Gabriel da Cachoeira, $1^{\circ} 10^{\prime} 46^{\prime \prime} \mathrm{S}$ 66 $50^{\circ} 26^{\prime \prime} \mathrm{W}, 20 \mathrm{Feb}$ 2014, V. Machado \& T. Hrbek. INPA 11804, 1, $176.3 \mathrm{~mm}$ SL, igarapé Paunini, tributary of rio Jaú, Parque Nacional do Jaú, rio Negro basin, Barcelos, 2¹2'44”S 62²3'47'W, 12 Jun 1995, M. Garcia \& E. Ferreira. INPA 18657, 4, 1 skel., 144.8-172.4 mm SL, lago Curirarra, 4 hours upstream rio Caurés, Barcelos, $1^{\circ} 20^{\prime} 04^{\prime \prime} \mathrm{S} 62^{\circ} 21^{\prime} 40^{\prime \prime} \mathrm{W}, 25$ Dec 1976, Expedition Negro-Caurés. NUP 17869, 1, 155.8 $\mathrm{mm}$ SL, same data as INPA 18657. INPA 34811, 2, 136.0$149.4 \mathrm{~mm}$ SL, collected with the holotype. INPA 37249, 2 , 107.2-113.8 mm SL, shore of rio Jatapu, São Sebastião do Uatumã, 201'03"S 58 10 '26"W, 1 Oct 2011, L. Rapp PyDaniel, G. Torrente-Vilara, R. P. Ota \& W. Pedroza. INPA 42313, 1, $95.3 \mathrm{~mm}$ SL, rio Padauari, Parque Estadual do rio Negro, Novo Airão, 2'09'26"S 60¹7'32”W, 13 Apr 2005, F. Medonça, A. Pires \& M. Picanso. INPA 46289, 3, 160.9-165.9 mm SL, rio Negro, Barcelos, 0³6’19”S 6321'25”'W, 19 Feb 2014, V. Machado \& T. Hrbek. INPA 46469, 2, 142.5-153.7 mm SL, rio Negro in front of Castanheira community, São Gabriel da Cachoeira, 0'20'04"S 65'38'18'W, 10 Feb 2014, V. Machado \& T. Hrbek. INPA 46472, 1, $153.1 \mathrm{~mm}$ SL, same data as ANSP 200146. INPA 52432, 5, 2 skel., 117.8-134.7 mm SL, lago do Acaricuara, rio Negro basin, Manaus, $3^{\circ} 04^{\prime} 55^{\prime} \mathrm{S}$ 59'57'38”'W, 18 Feb 2011, N. Penhalosa-Duarte, A. A. Peneira, A. L. A. Mesquita, D. M. M. Mendes \& M. F. Catarino. MZUEL 15328, 1, $135.0 \mathrm{~mm}$ SL, lago do Prato, rio Negro basin, Parque Nacional de Anavilhanas, Novo Airão, 243'02”S 6044'41'"W, 5 May 2016, J. L. O. Birindelli, F. Jerep, L. H. Rapp Py-Daniel, D. A. Bastos, R. P. Ota \& S. Hashimoto. Pará: INPA 39507, 3, 125.0-179.5 $\mathrm{mm}$ SL, lago Jacaré, rio Trombetas, Oriximiná, $1^{\circ} 20$ '48"S $56^{\circ} 51^{\prime} 17^{\prime}$ 'W, 30 Nov 2007, D. A. Bastos. MZUSP 119008 , 2, 129,2-130,7 $\mathrm{mm} \mathrm{SL}$, same data as INPA 39507. Roraima: INPA 19994, 3, 140.9-166.8 mm SL, lago do Uruaí, rio Branco, Caracaraí, c. $1^{\circ} 50^{\prime} \mathrm{S} 61^{\circ} 10^{\prime} \mathrm{W}, 27 \mathrm{Nov}$ 1976, E. Ferreira. Venezuela, Amazonas: MCNG 12414, 1, $160.9 \mathrm{~mm}$ SL, Río Pasimoni, approximately $20 \mathrm{~km}$ above

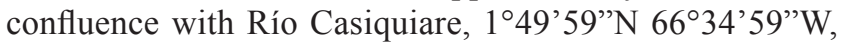
19 Apr 1985, L. N. P. Cardozo \& E. Casdon.

Diagnosis. Metynnis melanogrammus differs from all congeners by having highly concentrated dark chromatophores on the lateral-line scales, resulting in markedly dark pigmentation along the lateral line. Additionally, M. melanogrammus can be diagnosed from M. altidorsalis, $M$. anisurus, $M$. argenteus, M. cuiaba, $M$. guaporensis, M. lippincottianus, M. luna, M. maculatus, $M$. mola, M. otuquensis and M. polystictus by the possession of 13-18 gill-rakers on the upper limb and 16-24 on the lower limb (vs. 8-12, 11-14 in M. altidorsalis and $M$. argenteus; 8-10, 12-14 in M. cuiaba; 22-36, 25-38 in $M$. guaporensis and M. luna, 8-12, 10-14 in M. lippincottianus and M. maculatus; $7-10,12-15$ in M. mola; 8-11, 12-13 in M. otuquensis and 7-11, 11-15 in M. anisurus and $M$. polystictus). Metynnis melanogrammus differs from $M$. fasciatus by having a shorter head length, $24.3-27.5 \% \mathrm{SL}$ (vs. 28.0-33.7\%) and by a color pattern with dark blotches concentrated at the level of the lateral line and ventral to that region ( $v s$. wide dark bars reaching the ventral portion of body). Finally, it can be distinguished from $M$. hypsauchen and $M$. longipinnis by having more predorsal and lateralline scales: 56-65, 90-107, respectively ( $v s .36-54,65-82$ in M. hypsauchen; and 40-58, 74-94 in M. longipinnis).

Description. Morphometric data summarized in Table 1. Body extremely compressed, overall aspect of body elliptical, body deepest at vertical through dorsal-fin origin. Predorsal and postdorsal origin equal in length. Dorsal profile of head convex from mouth to vertical through anterior portion of eye, slightly concave from latter point to base of supraoccipital process, and convex from that point to dorsal-fin origin. Dorsal body profile very steep from snout to dorsal-fin origin and with strong posteroventral slope after this point. Dorsal-fin base straight. Body profile almost straight from dorsal-fin insertion to adipose-fin origin. Adipose-fin base gently convex. Head short and oval with ventral half of opercle approximately twice as large as dorsal half, with posterior margin surrounded by broad opercular membrane, covering up to four scales horizontally at point of greatest head length.

Ventral body profile convex with series of 19 to 24 $\left(23^{*}\right)$ simple prepelvic spines, followed by 6 to $9\left(8^{*}\right)$ broader, simple, well developed postpelvic spines, some with both anterior and posterior points. Additional 1 to 3 $\left(1^{*}\right)$ pairs of spines, composing ventral keel; total spines 28 to $34(32 *)$, never surpassing anus (Fig. 2). Caudal peduncle relatively short; profile of lower caudal peduncle slightly concave.

Snout slightly rounded. Mouth terminal with molariform teeth; jaws isognathous. Premaxillary teeth in labial row contacting teeth in lingual row. Five teeth in labial row and two in lingual row (Figs. 3a, b). Premaxillary teeth 1-3 in labial row with slightly sharp edges; teeth 1 and 2 separated laterally (Fig. 3a). Dentary with four teeth decreasing in size posteriorly (Fig. 3c); pair of symphyseal dentary teeth always present behind main series of teeth (Fig. 3d). Maxillary edentulous.

Scales cycloid, numerous, diminute, irregular in size. Lateral line complete with 90 to $107\left(97^{*}\right)$ perforated scales; first six or eight scales larger than remaining. Scales rows above lateral line 52 to $66\left(63^{*}\right)$. Scales rows below lateral line 53 to $69\left(60^{*}\right)$. Scales rows between adipose-fin origin and lateral line 30 to $35(34 *)$. Circumpeduncular scales 30 to $37\left(34^{*}\right)$. Predorsal scales 56 to $65\left(60^{*}\right)$. 
Table 1. Morphometric data of Metynnis melanogrammus, new species. $\mathrm{N}=$ Number of specimens, and SD $=$ standard deviation.

\begin{tabular}{|c|c|c|c|c|c|}
\hline & $\mathrm{N}$ & Holotype & Paratypes & Mean & SD \\
\hline Standard length $(\mathrm{mm})$ & 29 & 141.3 & $95.3-179.5$ & & \\
\hline \multicolumn{6}{|c|}{ Percentages of standard length } \\
\hline Head length & 29 & 26.8 & $24.3-27.5$ & 26.2 & 0.86 \\
\hline Body depth & 29 & 76.6 & $67.2-86.6$ & 74.0 & 4.47 \\
\hline Caudal-peduncle depth & 29 & 10.0 & $9.0-11.6$ & 9.9 & 0.55 \\
\hline Caudal-peduncle length & 29 & 8.0 & $7.2-11.5$ & 9.5 & 1.32 \\
\hline Predorsal length & 29 & 60.2 & $55.8-69.1$ & 59.9 & 2.49 \\
\hline Prepectoral length & 29 & 29.9 & $27.9-33.0$ & 29.7 & 1.28 \\
\hline Preanal length & 28 & 76.6 & $70.6-79.1$ & 75.2 & 2.38 \\
\hline Postdorsal length & 29 & 63.6 & $58.8-74.1$ & 65.1 & 2.80 \\
\hline Prepelvic length & 29 & 60.9 & $55.4-69.0$ & 58.5 & 2.57 \\
\hline Dorsal-fin length & 26 & 24.9 & $22.8-42.7$ & 29.1 & 4.83 \\
\hline Pectoral-fin length & 29 & 19.1 & $17.8-22.0$ & 19.8 & 1.10 \\
\hline Pelvic-fin length & 29 & 15.2 & $13.5-17.4$ & 14.6 & 0.82 \\
\hline Anal-fin length & 25 & 14.4 & $10.3-23.5$ & 15.3 & 3.01 \\
\hline Dorsal-fin base length & 28 & 22.7 & 21.3-26.2 & 23.7 & 1.23 \\
\hline Adipose-fin base length & 29 & 20.8 & $17.3-22.8$ & 19.3 & 1.25 \\
\hline Anal-fin base length & 28 & 39.2 & $36.0-46.6$ & 40.1 & 2.30 \\
\hline Base of supraoccipital process to dorsal fin distance & 29 & 45.3 & 42.4-54.9 & 46.0 & 2.36 \\
\hline Dorsal to adipose fin distance & 29 & 9.2 & $9.1-14.1$ & 10.9 & 1.09 \\
\hline Supraoccipital process length & 29 & 20.8 & $17.1-24.0$ & 19.7 & 1.59 \\
\hline Interorbital width & 29 & 11.5 & $10.8-13.6$ & 11.7 & 0.58 \\
\hline Orbital diameter & 20 & 9.3 & $7.8-10.6$ & 8.7 & 0.54 \\
\hline Snout length & 29 & 7.6 & $6.7-8.5$ & 7.4 & 0.42 \\
\hline \multicolumn{6}{|c|}{ Percentages of head length } \\
\hline Interorbital width & 29 & 42.8 & $41.9-49.6$ & 44.5 & 1.96 \\
\hline Orbital diameter & 29 & 34.6 & $30.4-39.2$ & 33.2 & 2.02 \\
\hline Snout length & 29 & 28.2 & $26.2-31.1$ & 28.4 & 1.28 \\
\hline
\end{tabular}

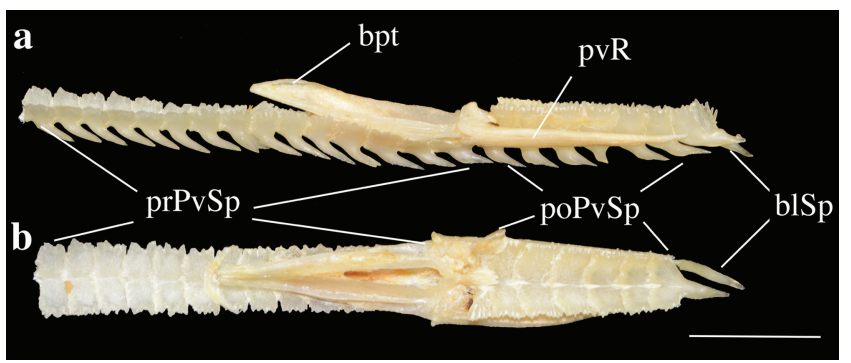

Fig. 2. Metynnis melanogrammus, INPA 18457, $144.8 \mathrm{~mm}$ SL. Abdominal spines: a. left lateral view; b. dorsal view. blSp, bilateral spine; bpt, basipterygium; poPvSp, postpelvic spines; prPvSp, prepelvic spines; pvR, pelvic-fin rays. Scale bars: $10 \mathrm{~mm}$.

Dorsal-fin rays ii, 16 to $19\left(18^{*}\right)$; not reaching adiposefin origin when adpressed; dorsal fin preceded by strong and forward-oriented spine. Dorsal-fin origin at mid-body or slightly posterior of vertical through pelvic-fin origin; dorsal-fin margin truncate. Adipose fin well-developed and extremely long with base longer than distance between dorsal-fin origin and adipose-fin origin. Adipose margin straight and truncate. Pectoral-fin rays i, 12(5) to $17\left(14^{*}\right)$ with distal margin convex, with anterior rays longer than remaining, forming rounded edge. Pelvic-fin rays i, 5 or $6\left(6^{*}\right)$ with distal margin convex, anterior rays slightly more elongate than remaining, forming rounded edge not reaching vertical through anal-fin origin when adpressed. Anal-fin rays iii, 33 to $41\left(39^{*}\right)$; with sexually dimorphic distal margin (see Sexual dimorphism, below); unbranched rays well-developed and joined into spine-like structure. Caudal fin forked, with lobes of similar size.

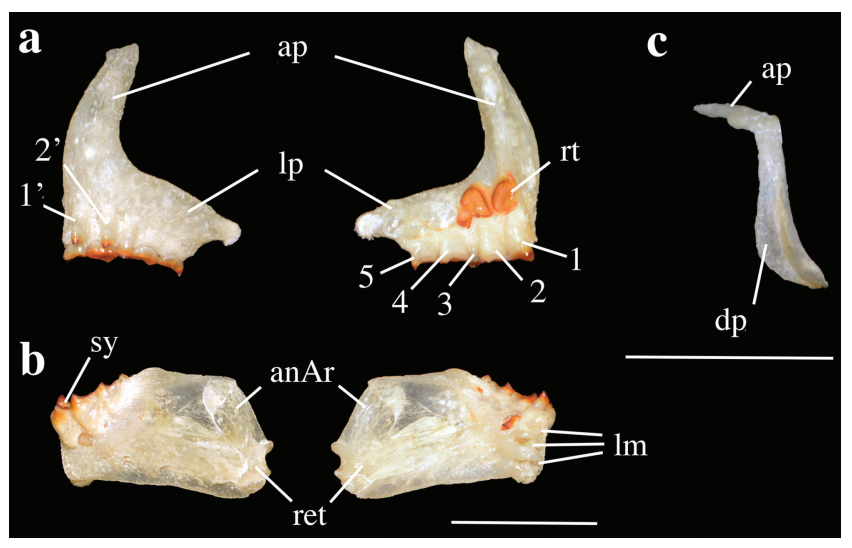

Fig. 3. Mandibular series of Metynnis melanogrammus, INPA 18457, $144.8 \mathrm{~mm}$ SL: a. labial and lingual view of premaxillary; b. labial and lingual view of dentary; c. maxillary. 1-5, teeth in labial row; 1'-2', teeth in lingual row; anAr, anguloarticular; ap, ascending process; dp, descending process; Im, lamellae at symphysis; lp, lateral process of premaxilla; ret, retroarticular; sy, symphyseal tooth; rt, replacement teeth. Scale bar: $10 \mathrm{~mm}$. 
First branchial arch with short gill rakers, 13 to 18 $\left(15^{*}\right)$ gill rakers on upper limb; 16 to $25\left(20^{*}\right)$ gill rakers on lower limb; lower gill rakers slightly longer than upper. Total vertebrae 37(3); abdominal vertebrae 12(3); caudal vertebrae 21(3). One vertebra (3) between verticals through last dorsal-fin pterygiophore and first anal-fin pterygiophore. Supraneurals 5(2), or 6(1).

Ostelogical description. Neurocranium high and triangular. - Olfactory region: Mesethmoid narrow, pointed and triangular anteriorly in dorsal view, dorsal profile convex in lateral view (Figs. 4a, b). Mesethmoid with narrow ventral process articulated to anterior region of vomer (Fig. 4a). Lateral wings of mesethmoid elongate, positioned on anterior half of bone. Lateral ethmoid elongate, dorsal portion reaching anteroventral surface of frontal, and lateral wing thin, pointed distally, and ventrally directed. Vomer excluded from limits of olfactory fossa, marked by longitudinal granulation on distal portion in ventral view (Fig. 4c). Nasal narrow, elongated, with well-defined canal (Fig. 4b). - Orbital region: Parasphenoid long and strongly curved ventrally (Fig. 4a), with ventral aperture forming two thin projections nearly parallel to each other (Fig. 4c) across ventral margins of prootic and basioccipital. Frontal subrectangular, relatively short, approximately 32\% of neurocranium length (Figs. 4a, b). Fontanel elongate. Epiphyseal bar dividing cranial fontanel; anterior fontanel oval to somewhat rounded, and posterior fontanel elongate (Fig. 4b). Neurocranium with slightly concavity at frontal bone (Fig. 4a). Pterosphenoid laminar, laterally articulated to sphenotic (Figs. 4a, c). Orbitosphenoid possessing two laterally compressed bony lamellae, anterior lamella upturned with anterior portion contacting frontal, and posterior lamella anteroventrally projected and almost reaching parasphenoid. - Otic region: Prootic trapezoidal, with anterodorsal circular aperture (Fig. 4a). Ventral margin of sphenotic concave, with pointed lateral spine for insertion of dilatator opercula. Parietal with dorsal surface sculptured by grooves, and posterior plate gradually becoming narrower. Intercalar diminute, laminar, very thin, and posteriorly located, covering articulation between exoccipital and pterotic. Pterotic quadrangular and possessing two-pointed posteroventrally directed processes covering lateral opening of posttemporal fossa. Epiotic solid with lateral arm extending towards posterior margins of parietal and pterotic, dividing posttemporal fossa into dorsal and ventral portions (Figs. 4a, b). - Occipital region: Basioccipital forming entire ventral surface of saccular capsule. Exoccipital surrounding lateral occipital foramen, lagenar capsule large. Supraoccipital spine long, well-developed, dorsal profile convex, and with distal portion curved down (Fig. 4a). Infraorbital series: Antorbital narrow and anteriorly curved. Five weakly developed infraorbitals forming semi-circle and leaving naked area on cheeks, not covering lateral surface of vertical arm of preopercle. Lateral branches of sensory channel of infraorbital 4 absent. Infraorbital 5 with "I" shaped sensory channel (Fig. 5a). Supraorbital oval and narrow with slightly convex anteroventral margin, not contacting infraorbital 5. Orbital region overall wide (Fig. 4a). Jaws: Premaxilla strongly attached to mesethmoid. Ascending premaxillary process elongate with distal tip gently pointed and slightly inclined in relation to lateral premaxillary process. Lateral premaxillary process subrectangular and well-developed, possessing dorso-lateral process with concavity for maxillary insertion. Four joined crypts of replacement teeth forming unique long replacement teethtrench on premaxillary (Fig. 3a). Descending arm of maxillary expanded and large, forming nearly right angle with ascending arm. Dentary rectangular and slightly arched with two to four rounded or oval replacement tooth-trenches, posterior trenches more elongate than anterior ones. Four bony lamellae at dentary symphysis. Symphyseal dentary teeth welldeveloped and surpassing dorsal edge of first tooth from main row. Retroarticular trapezoidal and contacting posteroventral portion of dentary. Anguloarticular elongate and articulated with quadrate by thin cartilage (Fig. 3b). Coronomeckelian approximately round. Hyopalatine or Pterygoid arch: Ascending process of quadrate perpendicular to longitudinal axis, shorter and wider than ventral process and with rectangular margin. Posterior margin of ventral process of quadrate not reaching vertical through symplectic's posterior tip. Hyomandibular narrow and elongate, with ventrally directed triangular projection along anterior margin. Endopterygoid trapezoidal. Symplectic small, located at metapterygoid-quadrate fenestra. Ectopterygoid toothless, narrow and oblique. Ecto-endopterygoid articulation delimiting insertion of posterior margin of autopalatine. Metapterygoid laminar, anteroventrally articulated with quadrate and posteroventrally with hyomandibular. Metapterygoid possessing diminute circular foramina bordered posteriorly by hyomandibular. Autopalatine subquadrangular with regular contour (Fig. 5b). Opercular series: Opercle narrow, laminar, and semicircular. Preopercle laminar and situated along ventral margins of quadrate and hyomandibular, with many grooves on ventral region, and entirely divided by ventrolaterally oriented median laterosensory canal. Interopercle laminar, narrow and somewhat triangular. Subopercle laminar, narrow and elongated, situated along ventral margin of opercle (Fig. 5b). Hyoid arch: Four branchiostegal rays, fourth longest. Anterior ceratohyal narrow and rectangular. Urohyal " $T$ " shaped in lateral view bearing thin dorsal flange. Dorsal hypohyal more developed than ventral hypohyal. Urohyal attached to anterior margin of ventral hypohyal. Interhyal small, narrow and articulated to hyomandibular and posteroventral portion of posterior certatohyal. Dorsal and ventral hypoyal almost equal in size. Basihyal narrow with dorsal portion larger than ventral portion (Fig. 5c). Branchial skeleton: Ceratobranchials 1-5 with 17-19 thin gill-rakers. Epibranchials 1-4 ossified with 13-16 thin gill-rakers, shorter than those from ceratobranchial; 5th epibranchial cartilaginous even in adults. Pharyngobranchials 1-4 ossified. Basibranchials 1-3 thin and ossified. Hypobranchials 1-3 with 2-3 thin gill-rakers. 
Weberian apparatus and associated centra: Compound centra 1 and 2 approximately equal in size, lateral process of centrum 2 well-developed, axially directed and elongate, ventrolateraly articulated with centrum 3. Centrum 4 largest. Neural arches 3 and 4 separated by suture, neural arch 3 small, and neural arch 4 bearing elongated neural spine of fourth vertebra, fused with supraneural 1. Intercalarium thin, and scaphium short. Inner arm of os suspensorium with robust posteriorlyoriented process. Outer arm of os suspensorium short and dorsoventrally flattened. Tripus aligned with intercalarium and lateral process of third centrum, with straight ventral margin. Claustrum with short ascending arm, and bearing triangular flange along dorsal margin. Neural complex with narrow posterior lamellar portion. Axial skeleton: All vertebrae with neural arches, neural spines and conical neural zygapophyses. Posteriorly directed triangular processes on first two ribs, second smaller. Precaudal vertebrae lack haemal spines and bear parapophyses articulating with ribs. Caudal vertebrae with haemal arches and ventral haemal spines, except vertebra 16, which lacks haemal spine. Pectoral girdle: Cleithrum well-developed with pointed dorsal distal tip extending to middle portion of supracleithrum. Supracleithrum elongate and bearing two small spine-like processes on middle portion of bone. Posttemporal thin, oblique and slightly curved with pointed dorsal distal tip, and elongated median transversal process. Extrascapular lamellar, small, and positioned anteroventral to posttemporal. Postcleithrum 1 oval and vertically elongate. Postcleithrum 2 vertically elongate with narrow lamellar posterior portion, and anterior portion overlapped by cleithrum. Postcleithrum 3 very elongate and pointed, extending beyond ventral margin of pectoral fin. Scapula with wide anterior process, and welldeveloped scapular foramen. Coracoid contacting cleithrum anterior- and posteriorly, with ventral margin curved. Mesocoracoid vertically oriented with dorsal portion articulated with middle region of horizontal process of cleithrum and ventral portion contacting coracoid (Fig. 5c, d). Pelvic girdle: Basipterigyum elongate with ischiac process long and pointed reaching first third of pelvic-fin rays; located above ventral margin of abdomen on dorsal margin of ventral spines (Figs. 2a, b). Dorsal fin: Twenty proximal-middle dorsal-fin radials, each with lateral lamellar process. Anterior proximal-middle dorsal-fin radial modified, reduced in size, and bearing anteriorly directed predorsal spine. Spine rounded with serrate dorsal surfasse. Anteroventral cavity of spine reduced or absent (Fig. 6a). Anal fin: Forty-one proximalmiddle anal fin radials, anterior three each with lateral lamellar process. Males with anterior lobe on anterior rays (Fig. 6b, see more details under Sexual dimorphism). Caudal fin and supporting skeleton: Epural 1 anteriorly situated, and epurals 1-2 filling all space between neural arch and spine of preural centrum 3, pleurostyle and uroneural 2. Haemal arches and spines of preural centra 2 and 3 well developed, narrow and fused. Hypural 1 well-developed, hypural 2 narrow, hypural 3 horizontally directed, hypural 4 proximate to hypural 5 and smaller. Hypural 2 not in contact with compound ural centrum. Neural arches and spines of preural centrum 2 and narrow and elongate. Parhypural proximate to hypural 1. Uroneural 2 narrow and proximate to pleurostyle. Principal caudal-fin rays 9+8 (Fig. 6c).

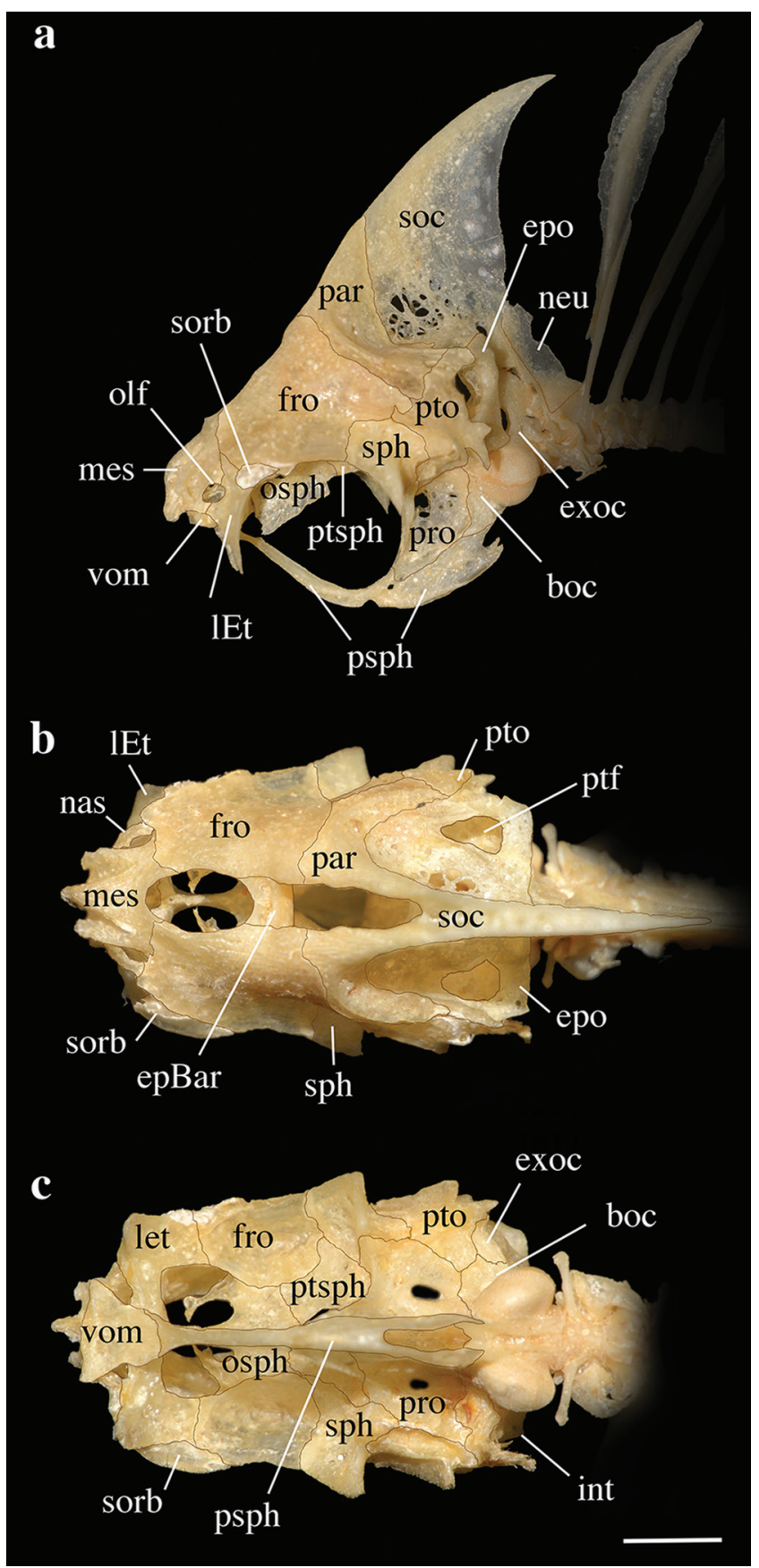

Fig. 4. Neurocranium of Metynnis melanogrammus, INPA 18457, $144.8 \mathrm{~mm}$ SL: a. lateral view; b. dorsal view; c. ventral view. boc, basi occipital; epBar, epiphyseal bar; epo, epiotic; exoc, exoccipital; fro, frontal; int, intercalar; IEt, lateral ethmoid; mes, mesethmoid; nas, nasal; neu, neural; olf, olfactory fossa; osph, orbitosphenoid; par, parietal; pro, prootic; psph, parasphenoid; ptf, posttemporal fossa; pto, pterotic; ptsph, pterosphenoid; soc, supraoccipital; sorb, supraorbital; sph, sphenotic; vom, vomer. Scale bar: $10 \mathrm{~mm}$. 


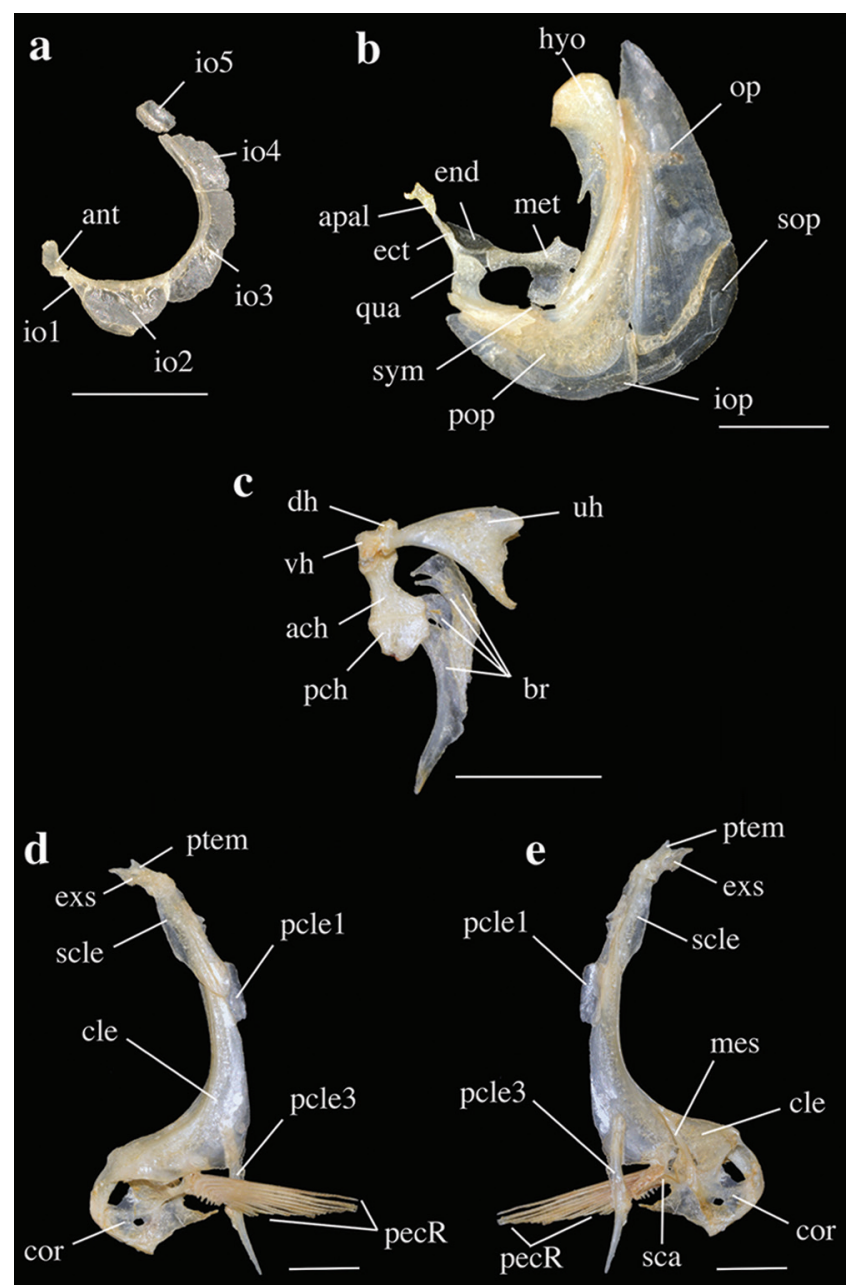

Fig. 5: Osteology of Metynnis melanogrammus, INPA 18457, $144.8 \mathrm{~mm}$ SL: a. hyopalatine and opercular series; $\mathbf{b}$, infraorbitals; c. hyoid arch; d. left pectoral girdle, lateral view; e. left pectoral girdle, medial view. ach, anterior ceratohyal; apal, autopalatine; ant, antorbital; br, branchiostegal rays; cle, cleithrum; cor, coracoid; dh, dorsal hypohyal; ect, ectopterygoid; end, endopterigoid; exs, extrascapular; hyo, hyomandibular; io1-5, infraorbital 1-5; iop, interopercular; mes, mesocoracoid; met, metapterygoid; op, opercle; pch, posterior ceratohyal; pcle1-3, postcleithrum 1-3; pecR, pectoral-fin rays; pop, preopercle; ptem, posttemporal; qua, quadrate; sca, scapula; scle, supracleithrum; sop, subopercle; sym, symplectic; uh, urohyal; vh, ventral hypohyal. Scale bars: $10 \mathrm{~mm}$.

Color in alcohol. Overall body coloration light-brown to yellow, head and body darker dorsally. Scales of lateral line with dark chromatophores, forming thin dark stripe along lateral line. Flanks with inconspicuous rounded or vertically elongate dark blotches on middle portion of body and ventral to lateral line. Males with small dark spots scattered irregularly over the body, but most concentrated above the lateral line and below the lateral line on the anterior body (Fig. 1a). Chromatophores can form a large irregular blotch over the supracleithrum, not surpassing posteriorly the vertical through the pectoral-fin's distal margin (Figs. 1a, b). Eye with broad dark transversal bar crossing pupil (not discernible in specimens retained for a long period in formalin). Dorsal, anal and caudal fins proximally hyaline and darker towards fin margins, with pigmentation along distal margin forming narrow dark stripe. Dorsal fin of mature specimens with vertically elongate dark spots or small dark stripes along interradial membranes. Pectoral and pelvic fins hyaline. Caudal fin with distally dark and diffuse band.

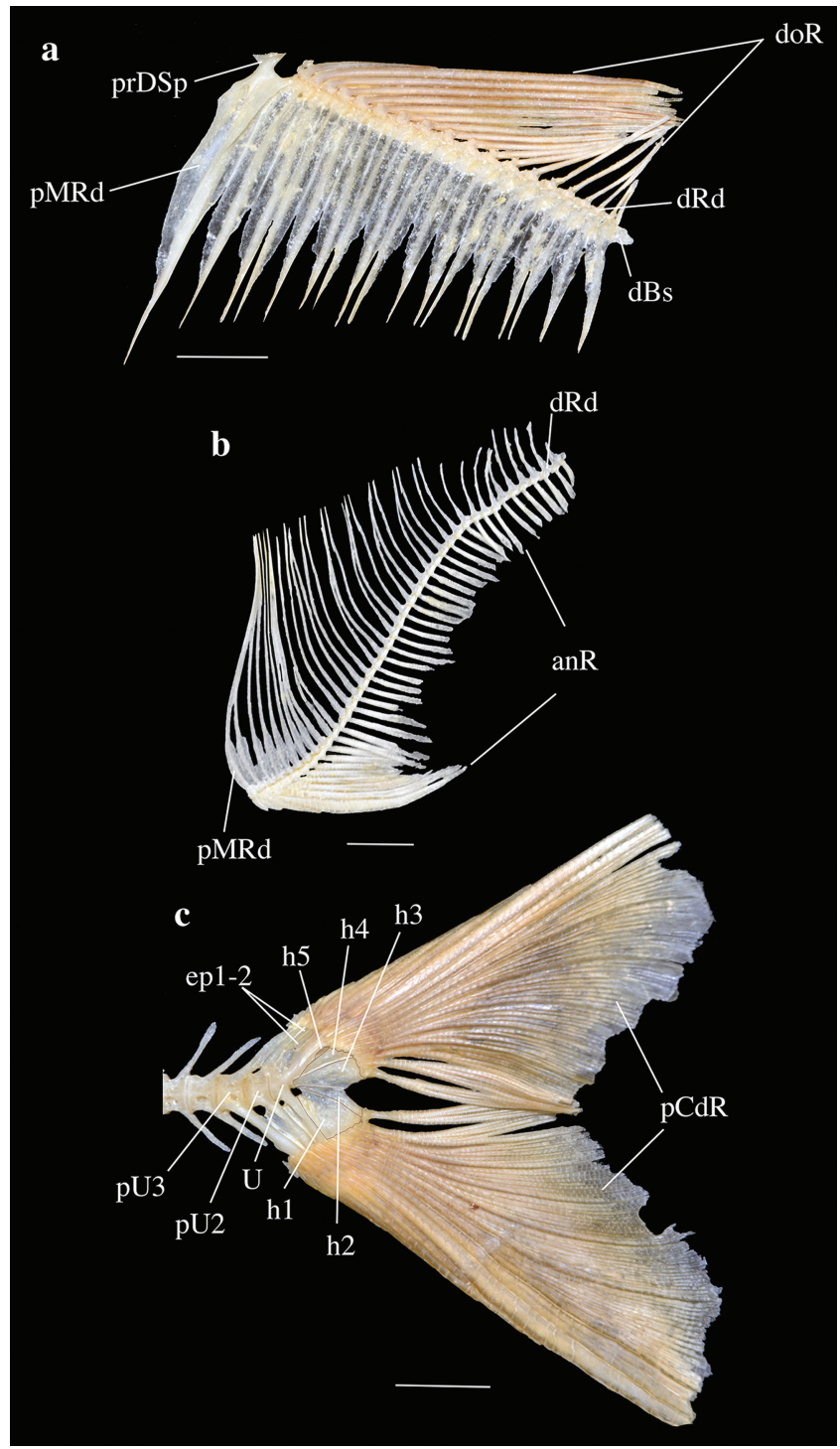

Fig. 6. Axial skeleton of Metynnis melanogrammus, INPA 18457, 144.8 mm SL: a. dorsal fin, left lateral view; b. anal fin, left lateral view; c. caudal fin, left lateral view; d. abdominal spines, left lateral view; e. abdominal spines, dorsal view. anR, anal-fin rays; blSp, bilateral spine; bpt, basipterygium; $\mathbf{d B s}$, dorsal bony stay; doR, dorsal-fin rays; $\mathbf{d R d}$, distal radial; ep1-2, epural 1-2; h1-5, hypural 1-5; pCdr, principal caudalfin rays; pMRd, proximal-middle radial; poPvSp, postpelvic spines; prDSp, predorsal spine; prPvSp, prepelvic spines; pU2-3, preural centrum 2-3; pvR, pelvic-fin rays; $\mathbf{U}$, compound ural centrum. Scale bars: $10 \mathrm{~mm}$. 
Color in life. Based on observations of freshly collected specimens, overall body color silvery. Except for pectoral fin, all fins light yellow in base coloration. Anterior rays of anal- and pelvic-fins orange to an intense red. During breeding period, males with intense vertically elongate and irregularly-shaped blood-red blotch near supracleithrum, situated between lateral line and the region just dorsal to prepelvic spines. Conspicuous red dots occasionally present over anterodorsal region of body, extending posteriorly to vertical through dorsal-fin insertion (Fig. 7).

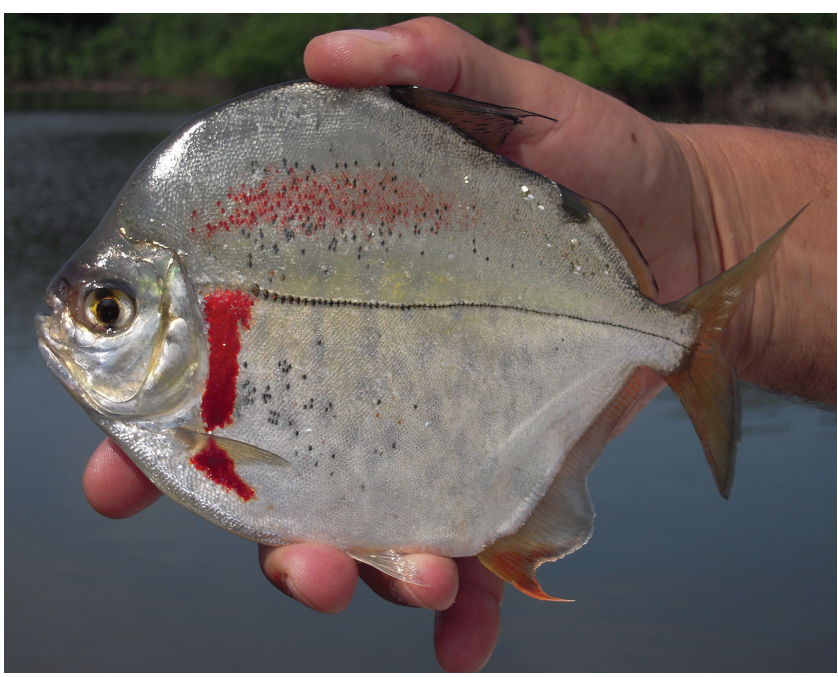

Fig. 7. Freshly collected Metynnis melanogrammus, male, not-preserved; lago do Aracu, rio Sucunduri, rio Madeira basin. Photo: A. Zenaid.

Sexual dimorphism. Metynnis melanogrammus presents the same sexual dimorphism illustrated by Zarske \& Géry (1999: 173) for $M$. hypsauchen and also recorded for $M$. guaporensis Eigenmann, 1915 by Ota et al. (2013). This dimorphism involves the presence in mature males of an anteriorly rounded lobe formed by an extention of the tenth to thirteenth branched rays of the anal-fin. This lobe has a concavity in the fin margin after the first two branched rays. With the exception of $M$. fasciatus, $M$. guaporensis, M. hypsauchen, M. longipinnis, M. luna, and M. melanogrammus, the males of remaining congeners possesses a continuous anterior lobe lacking the concavity (Ota, 2015). The anal fins of females and juveniles have only the anterior unbranched rays elongate, conferring a characteristic falcate feature to this fin.

Mature males also have more intense body coloration than females, marked by a blood-red, vertically elongated blotch on the supracleithrum region, and dark spots scattered across the body (see Color in alcohol and Color in life). Females only possess notable coloration on the anterior anal-fin rays, which are orange to light red. Prolongation of anterior dorsal-fin rays, which is very common in other Metynnis species (e.g., Metynnis cuiaba Pavanelli et al., 2009) was not observed either in males or females of $M$. melanogrammus.
Distribution. Metynnis melanogrammus is known from the rio Negro basin in Brazil and Venezuela, the Uatumã and Trombetas rivers, both of which are left-bank tributaries of the rio Amazonas, and from the rio Parauari, a right-bank tributary of the rio Amazonas. Zeinad \& Prado (2012) recorded the new species (as Metynnis cf. hypsauchen) at lago Aracu, rio Sucunduri (c. 5³5'59.83”'S 59³3'41.80”W, November 2009), a right-bank tributary of rio Madeira basin in Amazonas State, Brazil (Fig. 8). Despite a recent thorough survey of Serrasalmidae in the rio Madeira basin in Brazil (Ota et al., 2013), no preserved specimens of the new species from that basin are known.

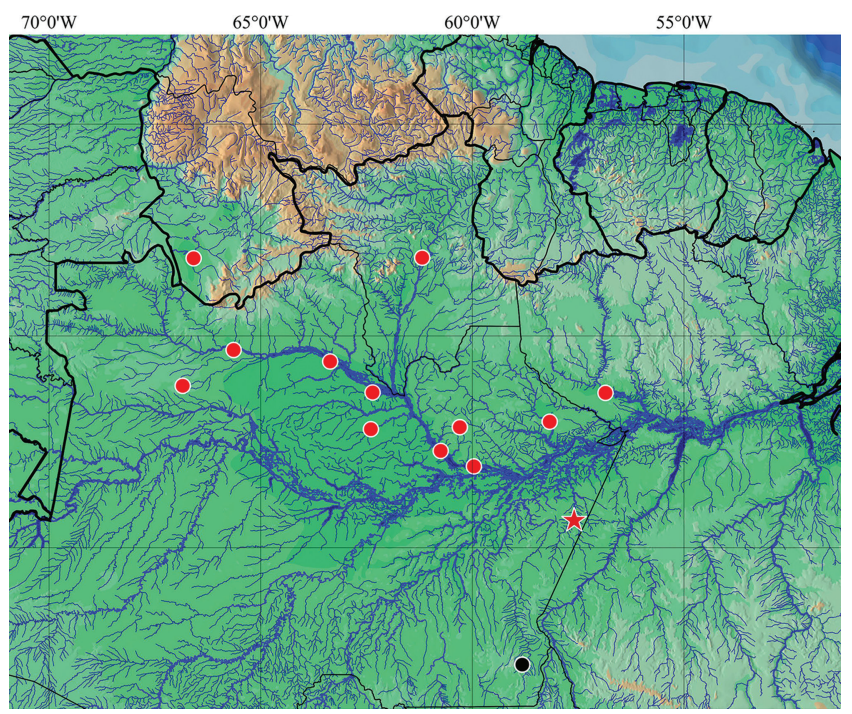

Fig. 8. Map of northern South America, including northern Brazil and southern Venezuela, showing distribution of Metynnis melanogrammus. The red star represents the type locality, red circles represent the paratype localities, and the black circle represents the locality on the rio Surunduri at which the live photograph of the new species (Fig. 7) was taken.

Ecological notes. Specimens of Metynnis melanogrammus are primarily found in lakes and rivers with dark-stained waters, such as the rio Negro in Brazil and Venezuela, and the rio Uatumã in Brazil. The new species has also been collected in clear water lakes in the Parauari (type locality), Trombetas and Sucunduri rivers, but is not known from white-water systems.

Examination of a dissected female (INPA 18657, 169.2 $\mathrm{mm} \mathrm{SL}$ ) collected in December revealed the possession of small, numerous, yellowish oocytes, typical of mature female during reproduction. An image of a freshly collected Metynnis melanogrammus (Fig. 7) taken in November, shows the typical breeding coloration of the species.

Etymology. From the Greak melas (black or dark) and gramma (letter), referring to the well-marked dark lateral line present in the new species. An adjective in the nominative singular. 
Conservation status. Metynnis melanogrammus is relatively common in the rio Negro basin, and is widely distributed along rivers from Northwestern South America in Brazil and Venezuela, with an Extent of Ocurrence (EOO) of approximately $522.458 \mathrm{~km}^{2}$. No specific threats were detected. Accordingly, we suggest that the new species be categorized as Least Concern (LC) according to IUCN criteria (IUCN, 2014).

Remarks. The new species described herein is similar to Metynnis hypsauchen in body shape, sexual dimorphism of the anal fin, and color pattern. Not surprisingly, analyzed material deposited at INPA and MCNG was misidentified as M. hypsauchen, and the species was recorded in the literature (Zeinad \& Prado, 2012) as Metynnis cf. hysauchen. The first obvious feature used to recognize specimens described herein as $M$. melanogrammus as a potentially new species similar to M. hypsauchen, is the presence of a markedly dark lateral line, a feature that is absent in M. hypsauchen. In addition, Metynnis melanogrammus possesses distinctly smaller scales than $M$. hypsauchen which is reflected by higher scale counts, i.e., predorsal (56-65 vs. 36-54), rows above and below lateral line (52-66, vs. 35-55), between adipose-fin origin and lateral line (30-35 vs. 19-25), and total perforated scales of the lateral line (90-107 vs. 65-82).

Ahl (1923) and Gosline (1951) regarded M. hypsauchen as the most common and widespread species of the genus. Indeed, Metynnis hypsauchen is widespread throughout the Amazon River system, in the Río Orinoco basin, and in some Guyanese rivers (e.g., Machado-Allison \& Fink, 1995; Jégu, 2003; Ota et al., 2013). This species occcurs in sympatry with Metynnis melanogrammus in the rio Negro basin of Brazil and Venezuela, and also in the rio Uatumã and rio Trombetas basins in Brazil. The new species is known from the rio Madeira basin solely by a photograph of a single specimen from the rio Surunduri (Fig. 7). There are no confirmed specimen records of $M$. hypsauchen in rio Madeira tributaries (Ota et al., 2013). The record of $M$. hypsauchen at the Aripuanã and Madeira rivers by Rapp Py-Daniel et al. (2007) was based on misidentifications of specimens of M. guaporensis and M. luna (R. P. Ota, pers. obs.).

\section{Discussion}

Taxonomic and phylogenetic relationships. Taxonomic confusion is rife in the literature dealing with Metynnis species. There are 28 nominal species and only around half of them are recognized as valid. The elevated number of synonyms is probably a consequence of the enormous variability of body shape and color pattern, which in turn are highly influenced by ontogeny and sexual dimorphism (Zarske \& Géry, 1999; Jégu, 2003; Pavanelli et al., 2009; Ota et al., 2013). As a consequence, there is little information about the phylogenetic relationships among species of Metynnis.
Therefore, along with the taxonomic description of Metynnis melanogrammus, its osteological description was presently provided to contribute to the knowledge on the evolutionary relationships of Metynnis. Some exclusive synapomorphies of the genus, previously highlighted by Machado-Allison (1982), were observed in $M$. melanogrammus. For example, the presence of intercalar reduced (Fig. 4c) forming the posterolateral corner of the neurocranium (Machado-Allison, 1982: 208, character 181); and predorsal spine type II (Fig. 6a), rounded in shape, with its dorsal surface serrated and anteroventral cavity reduced or even absent (Machado-Allison, 1982: 206, character 176).

Phylogenetic relationships of the genus are currently under study by the first author (RPO). According to Ota's (2015) previous results, Metynnis species are divided into two most inclusive monophyletic clades: the first composed by M. mola, M. cuiaba, M. otuquensis, M. altidorsalis, $M$. maculatus, M. anisurus and M. lippincottianus supported by eight synapomorphies, and the second by $M$. guaporensis, M. luna, M. fasciatus, M. hypsauchen, M. longipinnis, M. melanogrammus and an undescribed species. The latter clade is supported by eleven synapomorphies, including the presence of a concavity on anterior lobe of males anal-fin (character 30: 325) (Fig. 1a), and 26 to 40 total number of gill-rakers (character 44: 334).

Inside this clade, $M$. melanogrammus is most closely related to M. fasciatus, M. hypsauchen, M. longipinnis, and Metynnis sp. based on eight synapomorphies including the long and strongly downturned parasphenoid (character 142: 399) (Fig. 4a), and the lack of fusion of hypurals 1 and 2 (character 187: 423) (Fig. 6c). Metynnis fasciatus was recovered as sister to a polytomy composed of M. hypsauchen, M. longipinnis, M. melanogrammus and Metynnis sp. on the basis of five synapomorphies, including the narrow, laminar, and semicircular opercle (character 109: 373) (Fig. 5b), and the solid epiotic (character 173: 416) (Fig. 4a). Finally, $M$. melanogrammus was recovered as more closely related to Metynnis sp. than to M. hypsauchen, with that placement supported by five synapomorphies, including a unique shape of ectopterygoid among all congeners, which is short, narrow and oblique (character 119: 383) (Fig. 5b). In $M$. hypsauchen and most other Metynnis species, that bone is well-developed. However, these relationships are still under study, and represent a first hypothesis of relationhips among the Metynnis species.

In turn, the narrow and elongated form of the hyomandibular with a ventrally directed triangular projection on the anterior margin of the plate (Fig. 5b) is autapomorphic for M. melanogrammus. Machado-Allison (1982, plate XXXI, Ic) pointed out this feature and showed a drawing with a similar condition in a specimen assigned by that author to M. mola, a species endemic to the Paraguay River basin. However, this ventrally directed projection was not found in any specimen of M. mola examined in the phylogenetic analysis. Therefore we atribute this inconsistency to a possible misidentification of the specimen 
utilized by Machado-Allison (1982), who might have examined a specimen of M. melanogrammus instead. This species occurs in the rio Negro within Venezuela, where most of the samples used by that author originated.

Distribution pattern. The new species possesses an unusual distribution throughout blackwater rivers as the rio Negro and rio Uatumã, as well as clearwater rivers such as the Parauari, Trombetas and Sucunduri rivers. With the exception of the Parauari and Sucunduri rivers, the remaining rivers drain the Guiana Shield. The occurrences of Metynnis melanogrammus in both right- and left-margin tributaries of the Amazon deserve consideration. The species presents a wide distribution throughout the rio Negro basin (from above the Río Casiquiare in Venezuela to the rio Padauari, and lower rio Negro basin), and is also recorded from the rio Branco drainage and from rio Uatumã and rio Trombetas. This distribution clearly demonstrates broad historical connectivity among the drainages of the Guiana Shield, such as the rivers Orinoco, Negro and Branco. On the other hand, there are few records of $M$. melanogrammus from Amazon right margin tributaries, and specimens from both river margins are morphologically undistinguishable. Therefore, Metynnis melanogrammus could be considered to have a central Amazonian distribution pattern (F.C.T. Lima, pers. comm.) that also occur in black- and clearwater tributaries but not in milky, sediment-rich rivers, such as the Amazon or Madeira mainstems. This pattern suggests that sediment-loaded waters might work as a current barrier to M. melanogrammus distribution.

Comparative Material Examined. Metynnis altidorsalis: Brazil: Amazonas: INPA 17136, 4, 23.6-55.3 mm SL, rio Purus, Beruri. INPA 37095, 1, $116.9 \mathrm{~mm}$ SL, rio Solimões, Coari. INPA 39013, 1, 165.7 mm SL, rio Negro, Barcelos. INPA 39500, 4, 99.3-115.6 mm SL, rio Amazonas, Iranduba. MZUSP 92887, 1, $144.7 \mathrm{~mm} \mathrm{SL}$, rio Tiquié. Pará: INPA 34379, 4, 66.7-73.2 mm SL, rio Trombetas, Oriximiná. LBP 9331, 2, 95.8-107.6 mm SL, rio Guamá, Ourém. Roraima: INPA 41137, 8, 55.9-103.8 mm SL, rio Branco, rio Branco. Guyana: Rupununi: ANSP 180370, 1, 107.6 mm SL, Essequibo River, Massara village. ANSP 180371, 5 (11, 100.6107.7 mm SL), Takutu River, Lethem. ANSP 189573, 1, $77.7 \mathrm{~mm}$ SL, Essequibo River, Maipuri. Venezuela: Amazonas: MBUCV 8106, 16, 51,6-71.7 mm SL, Río Orinoco, San Fernando de Atabapo. MCNG 38265, 1, 122.5 mm SL, Río Manipitare. Apure: MBUCV 21070, 1, 59.5 mm SL, Río Apure, Mantecal. Bolivar: LBP 9997, 3, 90.0-106.8 mm SL, Río Orinoco, Caiçara del Orinoco. MCNG 36260, 1, $154.0 \mathrm{~mm}$ SL, Laguna de Aricagual, Sucre. MNHLS 5120, 1, $81.9 \mathrm{~mm}$ SL, Río Orinoco, Ciudad Guyana. Guárico: MHNLS 2530, 1, $160.1 \mathrm{~mm} \mathrm{SL}$, Río Aguaro. Monagas: MCNG 29038, 64.8 mm SL, Río Morichal Largo, El Rosário. Metynnis argenteus: Brazil: Pará: INPA 760, 3, 137.9145.7 mm SL, rio Curuã-Una, Santarém. MZUSP 3563, 2, 87.9$121.7 \mathrm{~mm}$ SL, rio Tapajós, Alenquer. MCP 21045, 1, $89.1 \mathrm{~mm}$ SL, ilha de São Miguel, Alenquer. Metynnis cuiaba: Brazil: Mato Grosso: LBP 8580, 1, $57.6 \mathrm{~mm}$ SL, rio Paraguai, Barra do Bugres. MZUSP 19814, 3, 38.3-43.1 mm SL, rio Paraguai, Cáceres.
MZUSP 90099, 2, 60.3-63.8 mm SL, rio Sepotuba, Cáceres. Mato Grosso do Sul: LBP 3216, 1, $80.5 \mathrm{~mm}$ SL, rio Taquari, Coxim. LBP 3742, 5, 128.9-138.3 mm SL, rio Negro, Aquidauana. MZUSP 39940, 2, 99.9-106.6 mm SL, Corixo at rio Taquari, Nhecolândia. Metynnis fasciatus: Brazil: Goiás: NUP 13032, 1, $56.8 \mathrm{~mm}$ SL, rio Araguaia, São Miguel do Araguaia. NUP 13041, 1, $55.6 \mathrm{~mm} \mathrm{SL}$, rio Araguaia, São Miguel do Araguaia. Mato Grosso: LBP 4001, 5, 83.9-93.9 mm SL, rio Araguaia, São Félix do Araguaia. NUP 13024, 2, 63.4-68.1 mm SL, rio Araguaia, Cocalinho. Pará: INPA 20449, 2, 74.3-122.7 mm SL, rio Araguaia, Caseara. MZUSP 20286, 1, 82.4 mm SL, rio Tapajós, Barreirinha. MZUSP 20555, 1, $121.7 \mathrm{~mm}$ SL and MZUSP 20576, 36, 91.4$101.2 \mathrm{~mm}$ SL, rio Capim, Paragominas. MZUSP 85847, 1, 61.2 $\mathrm{mm}$ SL, rio Amazonas, Almeirim. Metynnis guaporensis: Bolivia: INPA 658, 10, 44.9-57.3 mm SL, Río Blanco, Trindad. Brazil: Acre: LBP 4222, 3, 114.0-121.5 mm SL, rio Juruá, Cruzeiro do Sul. Rondônia: UFRO-I 407, 1, 104.5 mm SL, rio Madeira, Porto Velho. INPA 22407, 1, 84.5 mm SL, rio Pacaás Novos, GuajaráMirim. INPA 22408, 1, $97.9 \mathrm{~mm}$ SL, rio Guaporé, Pimenteiras. UFRO-I 759, $92.7 \mathrm{~mm} \mathrm{SL}$, rio Guaporé, Costa Marques. Metynnis hypsauchen: Brazil: Amazonas: INPA 4511, 1, $131.4 \mathrm{~mm} \mathrm{SL}$, rio Negro, Manaus. INPA 26878, 6, 108.1-124.4 mm SL, rio Uatumã, Presidente Figueiredo. INPA 27438, 2, 58.9-85.4 mm SL, rio Solimões, Coari. INPA 30702, 2, 99.1-103.1 mm SL, rio Negro, Novo Airão. INPA 32228, 1, $35.8 \mathrm{~mm}$ SL, rio Solimões, Tefé. INPA 34683, 1, 144.4 mm SL, rio Parauari, Maués. INPA 35599, 14, 86.6-146.6 mm SL, rio Aripuanã, Novo Aripuanã. INPA 37090, 1, 118.7 mm SL, rio Solimões, Alvarães. INPA 39497, 1, $82.9 \mathrm{~mm}$ SL, rio Negro, Barcelos. INPA 39498, 5, 45.5-59.6 mm SL, rio Uatumã, Balbina. MZUSP 77631, 44, 39.8-92.2 mm SL, rio Negro, São Gabriel da Cachoeira. Pará: MCP 15107, 1, 122.9 mm SL, rio Tapajós, Itaituba. MUSZP 19680, 14, 29.6-71.1 mm SL, rio Arari, Ilha do Marajó. Roraima: INPA 39021, 2, 138.4$142.6 \mathrm{~mm}$ SL, rio Branco, Caracaraí. Guyana: Siparuni: ANSP 175751, 1, 97.5 mm SL, Essequibo River, Maipuru. Venezuela: Amazonas: MCNG 47246, 1, 136.8 mm SL, Río Orinoco. Apure: MBUCV 19947, 1, 88.2 mm SL, Río Apure. Bolívar: MCNG 48251, 1, 83.2 mm SL, Laguna de Aricagua, Maripa. Guárico: MBUCV 23622, 2, 129.8-132.9 mm SL, Río Unare, Las Piedras. Portuguesa: MCNG 11281, 147.9 mm SL, Río Apure. Metynnis lippincottianus: Brazil: Amapá: MZUSP 63303, 7, 74.5-83.8 mm SL, rio Araguari, Ferreira Gomes. Amazonas: INPA 4607, 1, 103.3 mm SL, rio Solimões, Careiro da Várzea. INPA 39091, 1, 94.2 mm SL, rio Solimões, Manacapuru. INPA 39492, 1, $90.1 \mathrm{~mm} \mathrm{SL}$, rio Amazonas, Iranduba. Bahia: MZUSP 75092, 1, $89.3 \mathrm{~mm}$ SL, rio de Contas, Maracá. Goiás: NUP 2379, 26, 69.7-138.5 mm SL, rio Corumbá, Corumbaíba. Maranhão: INPA 733, 1, 90.3 mm SL, rio Pericumã, Pinheiro. MZUSP 36596, 7, 63.5-90.2 mm SL, Lago Cana Brava, Matões. Mato Grosso do Sul: NUP 9380, 1, $71.3 \mathrm{~mm}$ SL, rio Ivinheima, Jateí. NUP 9600, 5, 98.2-104.8 mm SL, rio Paraná, Três Lagoas. Minas Gerais: INPA 36822, 9, 84.9-111.8 mm SL, rio São Francisco, Três Marias. LBP 10360, 2, 70.7-98.4 $\mathrm{mm}$ SL, rio São Francisco, Pirapora. LBP 10475, 3, 50.8-55.6 mm SL, rio São Francisco, Paracatu. Pará: INPA 38325, 13, 64.4-80.4 $\mathrm{mm}$ SL, Ilha de Marajó, Igarapé Olho-no-olho, Salvaterra. LBP 5429, 5, 45.4-70.4 mm SL, rio Jari, Almeirim. LBP 9395, 3, $74.7-$ 
93.5 mm SL, rio Guamá, Ourém. MZUSP 105774, 2, 54.3-57.2 $\mathrm{mm}$ SL, rio Marapinim, bacia costeira, São Caetano de Odivelas. Paraná: CZUEL 288, 4, 82.4-115.4 mm SL, rio Tibagi, Sertanópolis. NUP 2700, 1, $98.2 \mathrm{~mm} \mathrm{SL}$, rio Paranapanema, Andirá boundery with Palmital. NUP 4687, 4, 116.8-136.6 mm SL, rio Paraná, São Miguel do Iguaçu. NUP 4689, 1, 109.9 mm SL, rio Paraná, Guaíra. NUP 6315, 1, 107.1 mm SL, rio Paraná, Diamante do Norte. Rondônia: MZUSP 19350, 1, 59.9 mm SL, rio Guaporé, Costa Marques. UFRO-I 409, 1, $107.8 \mathrm{~mm} \mathrm{SL}$, rio Madeira, Porto Velho. UFRO-I 4761, 1, 68.3 mm SL, rio Madeira, Santa Luzia do Oeste. rio Grande do Norte: MSL 28462, 2, 49.680.6 mm SL, rio Pium Paraná, Mirim. São Paulo: LBP 9116, 1, 98.6 mm SL, rio Paraná, Juritis. MZUSP 49917, 8, 49.7-61.7 mm SL, rio Grande, Pádua Sales. Sergipe: LBP 11525, 8, 21.2-35.7 mm SL, rio São Francisco, Gararu. Tocantins: INPA 20472, 1, $99.0 \mathrm{~mm}$ SL, rio Araguaia, Caseara. French Guiana: INPA 37079, 10, 1 c\&s, 55.0-62.1 mm SL, rio Oiapoque, Maripa boundary with Amapá, Brazil. Metynnis longipinnis: Brazil: Amazonas: INPA 37418, 1, 121.2 mm SL, rio Uatumã, São Sebastião do Uatumã. INPA 42314, 11, 39.1-81.0 mm SL, rio Negro, Manaus. Venezuela: Amazonas: MBUCV 11262, 1, 57.5 mm SL, Río Casiquiare, Solano. MBUCV 25068, 4, 42.8-54.4 mm SL, Río Ventuari. MCNG 26384, 1, 67.8 mm SL, Río Atabapo, San Fernando de Atabapo. MCNG 50135, 8, 54.7-84.0 mm SL, Río Manapiare, Juan de Manapiare. MHNLS 17282, 2, 54.0-83.5 mm SL, Río Orinoco. Bolívar: MBUCV 17211, 2, 49.9-54.5 mm SL, Río Orinoco, El Potrero. Guárico: MBUCV 23680, 17, 51.5-58.7 mm SL, Río Apure. Metynnis luna: Brazil: Amazonas: INPA 37093, 3 , 37.5-79.8 mm SL, rio Solimões, Fonte Boa. INPA 39501, 1, 93.1 $\mathrm{mm}$ SL, rio Amazonas, Iranduba. INPA 37094, 1, $95.5 \mathrm{~mm} \mathrm{SL}$, rio Solimões, Anori. INPA 39503, 1, 101.8 mm SL, rio Amazonas, Itacoatiara. INPA 38685, 3, 31.3-35.7 mm SL, rio Madeira, Nova Olinda do Norte. MZUSP 92129, 22, 37.0-51.7 mm SL, rio Tiquié, Serra da Mucura. Pará: LBP 9394, 1, 56.0 mm SL, rio Guamá, Ourém. MZUSP 5442, 1, 111.5 mm SL, rio Trombetas, Oriximiná. MZUSP 36822, 2, 72.6-87.0 mm SL, rio Xingu, Altamira. Rondônia: INPA 22406, 1, 88.6 mm SL, rio Guaporé, Surpresa. UFRO-I 410, 3, 89.1-89.4 mm SL, rio Madeira, Porto Velho. UFRO-I 1683, 2, 91.0-91.6 mm SL, rio Madeira, Jaciparaná. UFRO-I 4960, 3, 89.1-89.4 mm SL, rio Guaporé, Pimenteiras do Oeste. UFRO-I 8133, 3, 101.6-107.9 mm SL, rio Cautário, Costa Marques. Roraima: LBP 15530, 1, rio Takutu, Bonfim. MZUSP 19388, 5, 70.6-82.1 mm SL, rio Branco, rio Branco. Guyana: Siparuni: ANSP 175747, 3, 47.0-57.4 mm SL, rio Essequibo. Peru: Ucayali: Provincia Del Coronel Portillo: MZUSP 26285, 7, 48.1-83.0 mm SL, Río Ucayali, Cabococha. Venezuela: Amazonas: MCNG 38178, 1, $88.5 \mathrm{~mm}$ SL, Río Casiquiare, Solano. Anzoátegui: MCNG 29389,3, 41.4-42.5 mm SL, Río Orinoco, Ciudad Bolivar. Bolívar: MBUCV 14978, 45.6 mm SL, Río Orinoco, Puerto Páez. Metynnis maculatus: Brazil: Acre: LBP 18397, 1, 156.7 mm SL, rio Juruá, Cruzeiro do Sul. Mato Grosso: INPA 22375, 3, 125.7-148.9 mm SL, rio Guaporé, Costa Marques. INPA 43857, 1, 141.7 mm SL, rio Guaporé, Vila Bela da Santíssima Trindade. MZUSP 37853, 2, 149.8-158.5 mm SL, rio Guaporé, Vila Bela da Santíssima Trindade. Mato Grosso do Sul: LBP 18389, 1, 85.6 mm SL, rio Paraguai, Coxim. Rondônia: INPA
22374, 1, 149.2 mm SL, rio Pacaás Novos, Guajará-Mirim. UFRO-I 4287, 1, $13.9 \mathrm{~mm}$ SL, rio Madeira, Porto Velho. MZUSP 74539, 1, $98.0 \mathrm{~mm}$ SL, rio Madeira, Ariquemes. Metynnis mola: Brazil: Mato Grosso: LBP 8447, 3, 29.6-61.6 mm SL, rio Paraguai, Cáceres. MZUSP 90418, 10, 20.8-35.0 mm SL, rio Sepotuba, Cáceres. MZUSP 19796, 33, 54.7-66.5 mm SL, rio Paraguai, Poconé. NUP 2873, 3, 55.2-57.8 mm SL, rio Paraguai, Barão de Melgaço. NUP 5214, 1, $47.2 \mathrm{~mm}$ SL, rio Paraguai, Chapada dos Guimarães boundary with Nobres. Mato Grosso do Sul: LBP 35, 1, 48.9 mm SL, rio Miranda, Corumbá. MZUSP 36426, 9, 31.6$68.8 \mathrm{~mm}$ SL, rio Paraguai, Corumbá. LBP 3770, 7, 38.2-53.9 mm SL, rio Negro, Aquidauana. MZUSP 36735, 3, 30.2-33.5 mm SL, rio Paraguai, Itiquira. Metynnis otuquensis: Bolivia: FMNH 56919, 1, 62,1 mm XL, San Joaquim. Brazil: Mato Grosso: CPUFMT 122, 2, 62.0-65.3 mm SL, rio Cuiabá, Santo Antônio do Leverger. MZUSP 19814, 3, 38.3-43.1 mm SL, rio Paraguai, Cáceres. MZUSP 20429, 1, 119.5 mm SL, rio Pixaim, Barão de Melgaço. MZUSP 44326, $16(3$ measured, 62.6-65.1 mm SL), Arroio on rio Bugres, tributary of rio Paraguai, $13 \mathrm{~km}$ South of Nova Olímpia, Barra do Bugres. NUP 1066, 3, 36.6-38.2 mm SL, Manso Reservoir, tributary of rio Paraguai, Chapada dos Guimarães boundary with Nobres. NUP 3559, 1, 19.8 mm SL, Baía Sinhá Mariana, tributary of rio Paraguai, Barão de Melgaço. Paraguay: CAS 70841, 1, $88.9 \mathrm{~mm}$ SL, Río Otuquis, near the border with Bolivia, Alto Paraguay. FMHN 107894, 2, 57.1-65.0 mm SL, Riacho Miranda, tributary of Río Paraguay at Estancia Puerto Miranda. USNM 181699, 1, 57.4 mm SL, Río Paraguay, near Asunción. Metynnis polystictus: Brazil: Mato Grosso: LBP 15795, 3, 45.9-55.2 mm SL, rio Xingu, Querência. MCP 30244, 1, 47.4 mm SL, rio Xingu, Marcelândia. MZUSP 91739, 9, 23.7-52.1 mm SL, rio Culuene. MZUSP 94243, 24, 45.8-77.7 mm SL, rio Culuene. MZUSP 97583, 1, $114.3 \mathrm{~mm} \mathrm{SL}$, rio Iriri. MZUSP 101253, 2, 73.7-74.4 mm SL, rio Von den Steinen.

\section{Acknowledgements}

We are grateful to Otto Castillo and Oscar León (MCNG), Mariangeles Arce Hernandez and Mark Sabaj (ANSP) for museum and technical support. We thank Dave Catania (CAS), Caleb McMahan (FMNH), Aléssio Datovo and Willian Ohara (MZUSP), Jeff Williams and to the late Richard Vari (USNM), Alexandre Ribeiro (CPUFMT), Cláudio Oliveira (LBP), Francisco Provenzano (MBUCV), Carla Pavanelli (NUP), and Carolina Dória (UFRO) for the loan of specimens. We thank Alec Zeinad for providing Figure 6, and Renildo R. Oliveira (INPA) for assistance in taking and editing Figure 1. We also thank Flávio C. T. Lima (ZUEC) and Brian Sidlauskas (OSU) by constructive suggestions that improved this manuscript. Finally, we are also grateful to Valéria Machado, Izeni Farias and Tomas Hrbek (UFAM), who provided many specimens of the new species. This work was part of the Ph.D. thesis of RPO, who was supported by the Conselho Nacional de Desenvolvimento Científico e Tecnológico (fellowship CNPq \# 130778/2011-9); LRP was also supported by CNPq (grant \# 309392/2011-0). 


\section{References}

Ahl, E. 1923. Eine Revision de Characiniden-Gattung Metynnis. Ichthyologische Mitteilungen, 11: 15-31.

Calcagnotto, D., S. A. Schaefer \& R. DeSalle. 2005. Relationships among characiform fishes inferred from analysis of nuclear and mitochondrial gene sequences. Molecular Phylogenetics and Evolution, 36: 135-153.

Cione, A. L., W. M. Dahdul, J. G. Lundberg \& A. Machado-Allison. 2009. Megapiranha paranensis, a new genus and species of Serrasalmidae (Characiformes, Teleostei) from the upper Miocene of Argentina. Journal of Vertebrate Paleontology, 29: 350-358.

Cope, E. D. 1878. Synopsis of the fishes of the Peruvian Amazon, obtained by Professor Orton during his expeditions of 1873 and 1877. Proceedings of the American Philosophical Society, 17: 673-701.

Eigenmann, C. H. 1915. The Serrasalminae and Mylinae. Annals of the Carnegie Museum, 9: 226-272.

Eigenmann, C. H. \& C. H. Kennedy. 1903. On a collection of fishes from Paraguay, with a synopsis of the American genera of Cichlids. Proceedings of the Academy of Natural Sciences of Philadelphia, 55: 497-537.

Géry, J. 1972. Poissons characoïdes des Guyanes. I. Généralités. II. Familie des Serrasalmidae. Zoologische Verhandlung, 122: 1-249.

Gosline, W. A. 1951. Notes on the characid fishes of the subfamily Serrasalminae. Proceedings of the California Academy of Sciences, 27: 17-61.

IUCN Standards and Petitions Subcommittee. 2014. Guidelines for using the IUCN Red List Categories and Criteria, version 11, Standards and Petitions Subcommittee, Switzerland. Available from: http://www.iucnredlist.org/documents/ RedListGuidelines.pdf. (Date of acces - February 2014).

Jégu, M. 2003. Subfamily Serrasalminae (Pacus and piranhas). Pp. 182-196. In: Reis, R. E., S. O. Kullander \& C. J. Ferraris Jr. (Eds.). Check list of the freshwater fishes of South and Central America. Porto Alegre, Edipucrs.

Jégu, M. 2004. Taxonomie des Serrasalminae phytophages et phylogénie des Serrasalminae (Teleostei: Characiformes: Characidae). Unpublished $\mathrm{Ph}$. D. Dissertation, Museum National d'Histoire Naturelle, Paris, 423p.

Machado-Allison, A. 1982. Studies on the systematics of the subfamily Serrasalminae (Pisces-Characidae). Unpublished Ph. D. Dissertation, George Washington University, WashingtonD. C., 267p.

Machado-Allison, A. 1983. Estudios sobre la sistemática de la subfamilia Serrasalminae (Teleostei, Characidae). Parte II. Discusión sobre la condición monofilética de la subfamilia. Acta Biologica Venezuelica, 11: 145-195.

Machado-Allison, A. \& W. Fink. 1995. Sinopsis de las especies de la subfamilia Serrasalminae presentes em la cuenca del Orinoco. Serie Peces de Venezuela, Venezuela, Universidad Central de Venezuela, Faculad de Ciencias, 90p.
Mattox, G. M. T., R. Britz \& M. Toledo-Piza. 2014. Skeletal development and ossification sequence of the characiform Salminus brasiliensis (Ostariophysi: Characidae). Ichthyological Exploration of Freshwaters, 25: 103-158.

Ortí, G., P. Petry, J. I. R. Porto, M. Jégu \& A. Meyer. 1996. Patterns of nucleotide change in mitochondrial ribosomal RNA genes and the phylogeny of piranhas. Journal of Molecular Evolution, 42: 169-182.

Ortí, G., A. Sivansundar, K. Dietz \& M. Jégu. 2008. Phylogeny of the Serrasalmidae (Characiformes) based on mitochondrial DNA sequences. Genetics and Molecular Biology, 31: 343351.

Ota, R. P. 2015. Revisão taxonômica e filogenia morfológica de Metynnis Cope, 1878 (Characiformes: Serrasalmidae). Unpublished Ph. D. Dissertation, Instituto Nacional de Pesquisas da Amazônia, Manaus, 500p.

Ota, R. P., C. P. Röpke, J. Zuanon \& M. Jégu. 2013. Serrasalmidae. Pp: 15-47. In: Queiroz, L. J., G. Torrente-Vilara, W. M. Ohara, T. H. S. Pires, J. Zuanon \& C. R. C. Dória (Orgs.). Peixes do rio Madeira, volume II. São Paulo, Santo Antônio Energia.

Pavanelli, C. S., R. P. Ota \& P. Petry. 2009. New species of Metynnis Cope, 1878 (Characiformes: Characidae) from the rio Paraguay basin, Mato Grosso State, Brazil. Neotropical Ichthyology, 7: 141-146.

Rapp Py-Daniel, L. H., C. P. Deus, O. M. Ribeiro \& L. M. Sousa. 2007. Peixes. Pp. 89-25. In: Rapp Py-Daniel, L. H., C. P. Deus, A. L. Henriques, D. M. Pimpão \& O. M. Ribeiro (Orgs.). Biodiversidade do Médio Madeira: bases científicas para propostas de conservação. Série Biodiversidade 29. Manaus, INPA, MMA/MCT.

Thompson, A. W., R. Betancur-R., H. López-Fernández \& G. Ortí. 2014. A time-calibrated, multi- locus phylogeny of piranhas and pacus (Characi- formes: Serrasalmidae) and a comparison of species tree methods. Molecular Phylogenetics and Evolution, 81: 242-257.

Weitzman, S. H. 1962. The osteology of Brycon meeki: a generalized characid fish, with an osteological definition of the family. Stanford Ichthyological Bulletin, 8: 1-77.

Zarske, A. \& J. Géry. 1999. Revision der neotropischen Gattung Metynnis Cope, 1878. 1. Evalution der Typusexemplare der nominellen Arten (Teleostei: Characiformes: Serrasalmidae). Zoologische Abhandlungen Staatliches Museum für Tierkunde Dresden, 50: 169-216.

Zarske, A. \& J. Géry. 2008. Revision der neotypischen Gattung Metynnis Cope, 1878. II. Beschreibung zweier neuer Arten und zum Status von Metynnis goeldii Eigenmann, 1903 (Teleostei: Characiformes: Serrasalmidae). Vertebrate Zoology, 58: 173196.

Zeinad, A. K. \& R. A. Prado. 2012. Peixes fluviais do Brasil: espécies esportivas. Campinas, Pescaventura, 360p.

Submitted March 04, 2016 Accepted October 28, 2016 by Brian Sidlauskas 